\title{
Variation of Diatoms and Silicon in a Tributary of the Three Gorges Reservoir: Evidence of Interaction
}

\author{
Wei Xiao ${ }^{1,+}$, Yubo Huang ${ }^{2,+}$, Wujuan $\mathrm{Mi}^{2}$, Hongyan $\mathrm{Wu}^{1}$ and Yonghong $\mathrm{Bi}^{2, *}$ \\ 1 School of Civil Engineering, Architecture and Environment, Hubei University of Technology, \\ Wuhan 430068, China \\ 2 State Key Laboratory of Freshwater Ecology and Biotechnology, Institute of Hydrobiology, Chinese \\ Academy of Sciences, Wuhan 430072, China \\ * Correspondence: biyh@ihb.ac.cn \\ + Equally contributed.
}

Received: 16 May 2019; Accepted: 28 June 2019; Published: 2 July 2019

\begin{abstract}
To gain insight into the variation of diatoms and silicon and their interaction in a tributary of the Three Gorges Reservoir (TGR), the Xiangxi River was chosen as a representative tributary, and dissolved silicon (DSi) and biogenic silicon (BSi) were investigated monthly from February 2015 to December 2016, accompanied by diatom species composition and cell density analyses. The results showed that the diatom population and its relationship with silicon concentration were significantly different between the lacustrine zone and riverine zone $(P<0.05)$. The cell density in the lacustrine zone $\left(6.20 \times 10^{5} \sim 9.97 \times 10^{7}\right.$ cells/L) was significantly higher than that in the riverine zone $\left(7.90 \times 10^{4} \sim 1.81 \times 10^{7}\right.$ cells $\left./ \mathrm{L}\right)(P<0.01)$. Water velocity was a key factor in determining the diatom species composition. Centric diatoms were the dominant species in the lacustrine zone, and pennate diatoms were the primary species in the riverine zone, which indicated that centric diatoms outcompete pennate diatoms under the influence of the TGR's operation. BSi showed a significant linear relationship with the cell density. DSi had a significant negative relationship with the cell density in the lacustrine zone, while no significant relationship was found in the riverine zone. This meant that the main contributor to BSi was diatoms, but DSi was primarily affected by water discharge, not diatom uptake. It could be deduced that the spatiotemporal heterogeneity of diatom communities was influenced by the TGR's operation. Silicon cycling in the tributary was significantly affected by diatoms, and the current concentration of DSi was sufficient for diatom growth and showed no significant effects on the diatom community.
\end{abstract}

Keywords: diatom; cell density; dissolved silicon; biogenic silicon

\section{Introduction}

Silicon originates from rock weathering and is transported from land to the ocean mainly by rivers. It was estimated that 371 million tons of dissolved silicon (DSi) and 8835 million tons of particulate silicon (PSi) drain into the ocean every year from the continental surfaces in the world [1]. DSi and biogenic silicon (BSi) are considered bioavailable silicon in natural waters. DSi can be directly assimilated by algae and hydrophytes. BSi can contribute to DSi because of its regeneration in the water and sediment. The recycling of BSi provides the major source of soluble reactive silicon required for diatom proliferation [2]. Silicon is a key nutrient for diatom growth because it is a kind of necessary element to form the diatom's rigid cell wall [3]. BSi is generated when diatoms, plants and other organisms uptake DSi during photosynthesis, and it is an important source of DSi due to its typically amorphous form; it plays an important role in the earth's Si cycle. DSi mainly originates from weathering, and anthropogenic activities can scarcely compensate for the loss of DSi from this 
source. Dsi and Bsi are not two independent variations in the water. With plenty of time, DSi can be converted to biological available silicon (BSi). When water velocity is high, the hydraulic retention time is short and can't meet the need of converting procedure. Thus, in the lacustrine area, diatom could deplete DSi and produce BSi in a stable environment. Decreased silicon has been observed in many rivers and lakes worldwide [4-6]. Diatom growth is related to silicate and other nutrient availability. Under conditions in which the silicate concentration was higher than $2 \mu \mathrm{mol} / \mathrm{L}$ and other nutrients were sufficient, diatoms were observed to dominate the phytoplankton community, accounting for more than $70 \%$ of the total cell density in the community [7]. The distribution patterns of epipelic and epipsammic diatoms were related to nutrient availability, especially of silicate and ammonium [8]. It was observed that silicate availability by river supply and strong tidal mixing of the water column seemed to determine the year-round dominance of diatoms over dinoflagellates in a Spanish estuary [9]. Studies also found that the ratio between silicates and other nutrients, such as carbon, nitrogen, or phosphorus, affected diatom growth in the phytoplankton succession. Skeletonema costatum is influenced by silicate availability and by changes in dissolved inorganic carbon (DIC) pool [10]. Species succession from diatom to blue-green algae was controlled by carbon and silicate in karst cascade reservoirs in Southwest China [11]. It has been proven that decreasing silicon and increasing nitrogen and phosphorus in the Yangtze River estuary resulted in eutrophication, decreased diatom composition in the algal community and frequent harmful algal blooms in coastal waters [12]. Therefore, there was a direct causal relationship between diatom growth and silicate availability.

In addition to silicate availability, algal growth is primarily related to changes in environmental factors, such as the water stability, water renewal rate and water retention time. In reservoirs with considerable hydraulic dynamics, the water renewal rate explained the selection of secondary species, and dominant species adapted to a broad range of environmental conditions [13]. Fast growth was the response of diatoms to changes in physical environmental factors, especially the daily variations in river discharge, which continuously modify the suspended particulate matter concentrations and water retention time [14], while low flow conditions lead to a progressive depletion of dissolved silicon [15]. On the other hand, diatom species varied depending on the environmental conditions. In comparison with pennate diatoms, centric diatoms favour relatively lower temperatures and photoperiods. Pennate diatoms depend more on light and grazer abundance [16]. Therefore, the relationship between diatoms and environmental factors is complex and requires further research.

Three Gorges Reservoir (TGR) is the largest deep river-type reservoir in the world. Large amounts of nutrients and pollutants from headwaters and tributaries drained into the reservoir after Three Gorges Dam began operation, causing severe problems such as eutrophication [17] and algal bloom [18]. Many studies have been conducted to elucidate algal succession [19] and nutrient distribution under TGR's operation [20-24]. It was observed that the frequency and duration of algal blooms has risen in recent years [25]. Furthermore, water intrusion from the main channel of the Yangtze River to the tributaries has worsened eutrophication in tributaries such as the Daning River [26] and the Xiangxi River [27]. Consequently, biogeochemical cycling of some nutrients, such as nitrogen, phosphorus, and silicon, has changed. Previous studies have demonstrated silicon retention in the TGR due to dam construction and its impact on the silicon efflux to the eastern sea through the Yangtze River $[5,28,29]$. These studies mainly focused on silicon dynamics and its fluxes. Other studies have emphasized algal succession and its relationship with nitrogen and phosphorus in the TGR [30]. However, the relationship between diatoms and silicon in the TGR has not yet been investigated in detail. After the impoundment of the TGR, silicon retention in the reservoir was increased, and the discharge amount of biogenic silicon was gradually reduced. Lower water velocity and higher water transparency accelerated the growth of diatoms and led to frequent diatom blooms in the tributaries of the TGR. In this study, the Xiangxi River was selected as a representative of the tributaries in the TGR, and silicon and diatoms were screened in two distinct zones: The riverine zone and the lacustrine zone. This study aims to understand (i) the diatom community in different water areas of the TGR and (ii) the interactive relationship between the available silicate or hydrodynamics and the diatom 
community in the TGR. A monthly investigation was conducted, including diatom species, cell density, silicon concentration, and environmental parameters. This study will help us to gain insight into the interaction between silicon concentration and diatom communities in the TGR and the variation of silicon and changes in the diatom community.

\section{Materials and Methods}

\subsection{Study Site}

The water level of the TGR was artificially regulated according to the dam operation strategy. In summer, the water level was low for power generation and flood prevention, and in winter, the water level was high for drought relief and navigation improvement. A typical hydrological year of the TGR was divided into four periods according to a series of specific operations. The impounding period was in autumn from September to October, and the water level increased from $145 \mathrm{~m}$ to $175 \mathrm{~m}$. The next three months (November to January) were the high water level period, with the water level maintained at approximately $175 \mathrm{~m}$. Then, in the discharge period (February to June), the water level was decreased from $175 \mathrm{~m}$ to $145 \mathrm{~m}$. The last period (July to August) was the low water level period, with the water level remaining at $145 \mathrm{~m}$. The water discharge and sand transport rate displayed opposite trends against the water level in the TGR, which was caused by seasonal variations in precipitation [31].

The source of the Xiangxi River is in the Shennongjia Forest in Western Hubei Province. Its location is $30^{\circ} 57^{\prime} \mathrm{N}-31^{\circ} 34^{\prime} \mathrm{N}, 110^{\circ} 25^{\prime} \mathrm{E}-111^{\circ} 06^{\prime} \mathrm{E}$, the length is $94 \mathrm{~km}$, and the watershed is approximately $3100 \mathrm{~km}^{2}$. The Xiangxi River contains three main tributaries: the Shendu River, the Baisha River and Gaolan Bay. The TGR does not affect the upstream area of the Xiangxi River; so, this zone is still highly canopied by riparian vegetation and remains the riverine type. In contrast, the canopy of the middle and downstream regions is not well developed due to the wider riverway and inconspicuous riparian zone. Therefore, this zone has changed to the lacustrine type.

Twelve sample zones were set along the Xiangxi River (Figure 1). Sample stations XX01 XX08 were located in the main channel from the estuary to the upstream region (Figure 1). There was one sample site in each of the two tributaries, the Baisha River (Site BSH), and the Shendu River (Site SDH). Two sample zones, GL01 and GL02, were set in Gaolan Bay. Water samples were not collected in XX08 in summer because of the usage of cascade hydropower stations. These sample zones were classified into the lacustrine zone (XX01 XX08 and GL01, GL02) and the riverine zone (BSH and SDH). They were selected to represent a wide range of environmental gradients under the influence of the Three Gorges Dam.

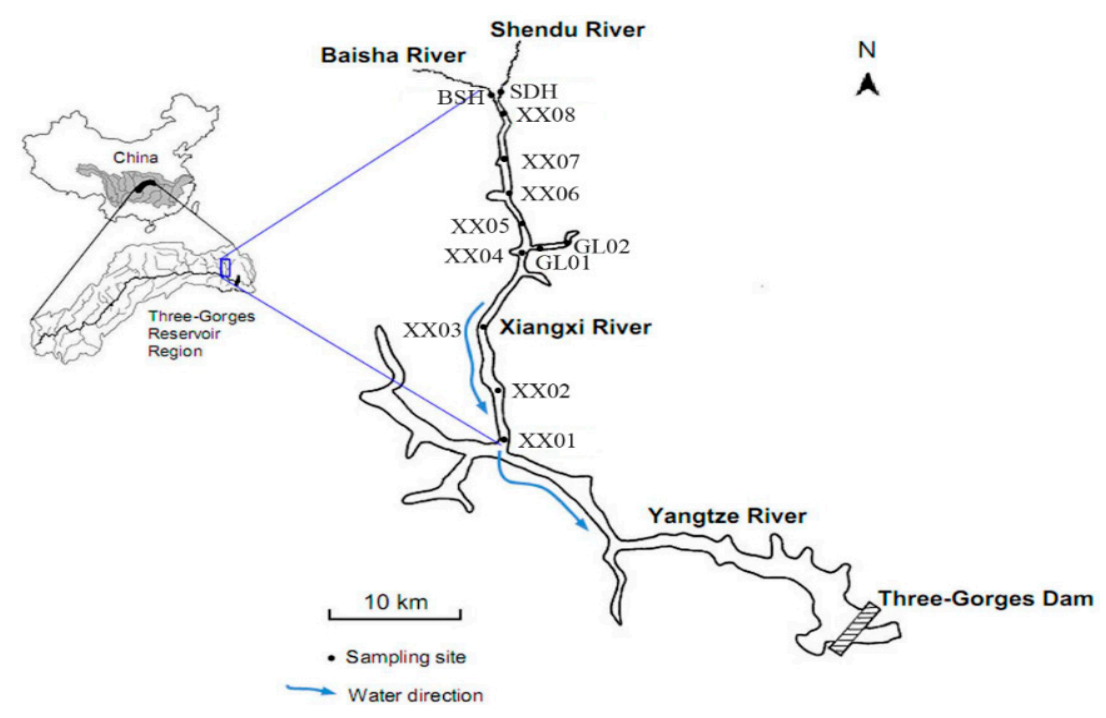

Figure 1. Sketch map of sampling stations in the Xiangxi River. 


\subsection{Sampling and Testing}

Monthly samples were collected from February 2015 to December 2016. Surface water samples $(0.5 \mathrm{~m})$ were collected with Van Dorn sampler at each site for three times. Samples for quantitative phytoplankton analyses were fixed with neutral Lugol's solution and concentrated after $48 \mathrm{~h}$ of sedimentation. Transparency (SD) was measured with a Secchi disk. Surface water velocity (Fv) was detected by SVRTM (Decatur Electronics Inc.: San Diego, California, USA), a hand held electronic wave water velocity detector. Dissolved oxygen (DO), $\mathrm{pH}$, water temperature (WT), turbidity (Turb), oxidation-reduction potential (ORP), and conductivity (Cond) were measured by a Eureka Manta 2 multiparameter probe (Eureka, Austin, TX, USA).

Before collecting samples, the bottles were pre-rinsed with $10 \% \mathrm{HCl}$ and distilled water three times. To determine DSi, samples were filtered through $0.45 \mu \mathrm{m}$ cellulose membrane filters. Using the silicomolybdic blue method, the filtrates were analyzed by a Skalar San++ autoanalyzer (Skalar Corporation, Breda, the Netherlands) with a precision of $2 \%$. The BSi was measured by the double wet-alkaline digestion method. The filter sample was submitted to a first digestion $(\mathrm{NaOH}, 0.2 \mathrm{M}, 4 \mathrm{ml}$; $\mathrm{pH}: 13.3)$ at $100^{\circ} \mathrm{C}$ for 40 minutes, and all $\mathrm{BSi}$ and a portion of the lithogenic silica were converted into $\mathrm{Si}(\mathrm{OH})_{4}$. Therefore, we can analyse the concentrations of $\mathrm{Si}$ and $\mathrm{Al}\left([\mathrm{Si}]_{1}\right.$ and $\left.[\mathrm{Al}]_{1}\right)$ in the supernatant. Then, after rinsing and drying (freeze drying at $-60^{\circ} \mathrm{C}$ ), the filter sample was digested again under the same conditions as in the first digestion. In this way, we can determine the (Si: $\mathrm{Al})_{2}$ ratio, which is the silicate minerals present in the sample. The exact biogenic silica concentration is calculated by the equation below:

$$
[\mathrm{BSi}]=[\mathrm{Si}]_{1}-[\mathrm{Al}]_{1}(\mathrm{Si}: \mathrm{Al})_{2}
$$

where the $[\mathrm{Si}]_{1}$ and $(\mathrm{Si}: \mathrm{Al})_{2}$ have been measured. The concentration of $\mathrm{Al}$ was determined by ICP-OES [32]. Water samples used for the $\mathrm{Chl}$ a measurement were filtered with a Whatman GF/C filter, and the residuals were extracted using $90 \%$ acetone solution in the dark for $24 \mathrm{~h}$ at $4^{\circ} \mathrm{C}$. Chl a was analyzed spectrophotometrically according to American public health association (APHA, 1995) [33]. Chemical oxygen demand (COD) was analyzed according to APHA (1995) [33].

Phytoplankton samples were preserved by adding $1 \mathrm{~mL}$ Lugol's solution to $100 \mathrm{~mL}$ sample and then stored in the dark. Samples settled for $48 \mathrm{~h}$ and were then siphoned and concentrated to $30 \mathrm{~mL}$. After complete mixing, $0.1 \mathrm{~mL}$ of the concentrated sample was counted directly in a counting chamber at 400× magnification with a light microscope (Olympus BX41). The identification of phytoplankton species was performed according to $\mathrm{Hu}$ and Wei [34].

\subsection{Statistical Analysis}

Origin 9.1 (OriginLab Corporation, Northampton, MA, USA) was used for mapping the concentration patterns [35]. Statistical analysis was carried out with SPSS 19.0 (International Business Machines Corporation, Amund, NY, USA) [36]. A t-test was used to compare the means of silicon concentration and diatom cell density between the lacustrine zone and the riverine zone [37]. Spearman analyses were performed to determine the relationships among diatom cell density and environmental factors [38]. A linear regression model was performed to determine the effect of diatom cell density on the silicon concentration. Prior to analysis, a dataset that did not fulfill the normality and homoscedasticity requirements was logarithmically transformed by $\log _{10}(x+1)$. Redundancy analysis (RDA) was performed to explore the relationship between the diatom community composition and environmental data using CANOCO version 4.5 (Wageningen University \& Research, Wageningen, the Netherlands) [39]. Diatoms were used as categorical environmental variables, and the other selected environmental variables were standardized by zero-mean normalization. The minimum number of measured environmental variables that could account for most of the variance in the species data was determined by forward selection with a permutation test at $P<0.05$. 


\section{Results}

Overall, sites in the upper river exhibited higher $\mathrm{pH}, \mathrm{DO}$ and turbidity but lower water temperature and SD values than sites in the lower river. Specifically, the riverine zone (BSH and SDH) exhibited higher water velocity than the lacustrine zone (XX01 XX08). The conditions were more homogenous during the dry season than during the wet season when the water level was high (Table 1).

Table 1. Environmental conditions ( $\mathrm{pH}$, water temperature (WT), dissolved oxygen (DO), flow velocity $(\mathrm{Fv})$, oxidation-reduction potential (ORP), transparency (SD), and turbidity (Turb)) at each site.

\begin{tabular}{cccccccc}
\hline Site & $\mathbf{p H}$ & $\mathbf{W T}\left({ }^{\circ} \mathbf{C}\right)$ & $\mathbf{D O}(\mathbf{m g} / \mathbf{L})$ & $\mathbf{F v}(\mathbf{m} / \mathbf{s})$ & ORP $(\mathbf{m V})$ & SD $(\mathbf{c m})$ & Turb $(\mathbf{N T U})$ \\
\hline XX01 & $8.48 \pm 0.37$ & $20.98 \pm 5.34$ & $9.09 \pm 1.45$ & $0.42 \pm 0.14$ & $166.91 \pm 51.20$ & $233.91 \pm 84.30$ & $1.71 \pm 0.99$ \\
XX02 & $8.54 \pm 0.37$ & $21.2 \pm 5.39$ & $9.32 \pm 1.27$ & $0.45 \pm 0.14$ & $162.74 \pm 50.16$ & $227.83 \pm 91.65$ & $1.49 \pm 0.80$ \\
XX03 & $8.39 \pm 0.35$ & $20.97 \pm 5.06$ & $8.88 \pm 1.41$ & $0.43 \pm 0.11$ & $159.80 \pm 50.18$ & $234.13 \pm 91.73$ & $1.71 \pm 0.95$ \\
XX04 & $8.40 \pm 0.39$ & $20.80 \pm 5.16$ & $9.01 \pm 2.30$ & $0.47 \pm 0.21$ & $173.83 \pm 57.46$ & $243.48 \pm 92.32$ & $1.66 \pm 0.86$ \\
GL01 & $8.43 \pm 0.39$ & $21.01 \pm 5.05$ & $9.20 \pm 2.52$ & $0.47 \pm 0.17$ & $176.93 \pm 59.30$ & $232.17 \pm 93.17$ & $2.50 \pm 2.96$ \\
GL02 & $8.55 \pm 0.46$ & $21.02 \pm 5.05$ & $9.80 \pm 3.26$ & $0.33 \pm 0.11$ & $174.64 \pm 63.73$ & $253.70 \pm 119.57$ & $2.47 \pm 2.97$ \\
XX05 & $8.49 \pm 0.42$ & $21.09 \pm 5.30$ & $9.32 \pm 1.96$ & $0.44 \pm 0.13$ & $144.57 \pm 56.22$ & $250 \pm 102.11$ & $1.50 \pm 0.98$ \\
XX06 & $8.58 \pm 0.46$ & $20.63 \pm 5.23$ & $9.62 \pm 2.50$ & $0.36 \pm 0.09$ & $138.32 \pm 57.41$ & $217.83 \pm 122.13$ & $2.32 \pm 2.43$ \\
XX07 & $8.61 \pm 0.48$ & $20.48 \pm 4.92$ & $10.00 \pm 2.92$ & $0.30 \pm 0.11$ & $140.60 \pm 53.88$ & $201.09 \pm 127.30$ & $5.12 \pm 5.20$ \\
XX08 & $8.57 \pm 0.5$ & $18.40 \pm 4.04$ & $10.77 \pm 4.19$ & $0.42 \pm 0.15$ & $156.46 \pm 49.58$ & $259.29 \pm 114.79$ & $1.94 \pm 1.92$ \\
BSH & $8.6 \pm 0.61$ & $18.31 \pm 3.70$ & $10.32 \pm 3.02$ & $0.61 \pm 0.28$ & $164.55 \pm 53.96$ & $156.74 \pm 125.51$ & $7.14 \pm 7.32$ \\
SDH & $8.63 \pm 0.4$ & $18.96 \pm 4.08$ & $9.93 \pm 2.55$ & $0.93 \pm 0.56$ & $168.89 \pm 53.58$ & $163.57 \pm 123.36$ & $7.00 \pm 7.14$ \\
\hline
\end{tabular}

The value was expressed as the average value \pm SD.

\subsection{Variation of Silicon Availability and Diatom Cell Density}

The concentration of DSi fluctuated more in the riverine zone (varying from $48.03 \mu \mathrm{mol} / \mathrm{L}$ to $105 \mu \mathrm{mol} / \mathrm{L}$, with an average value of $77.00 \pm 16.85 \mu \mathrm{mol} / \mathrm{L}$ ) than that in the lacustrine zone (ranging from $59.58 \mu \mathrm{mol} / \mathrm{L}$ to $102.85 \mu \mathrm{mol} / \mathrm{L}$, with an average value of $83.23 \pm 12.59 \mu \mathrm{mol} / \mathrm{L}$ ) (Figure 1 ). DSi in the lacustrine zone was significantly higher than that in the riverine zone $(t=2.312, P=0.024)$. The DSi concentration was higher in the winter and spring seasons, but decreased to a low level in the summer and autumn seasons (Figure 2).

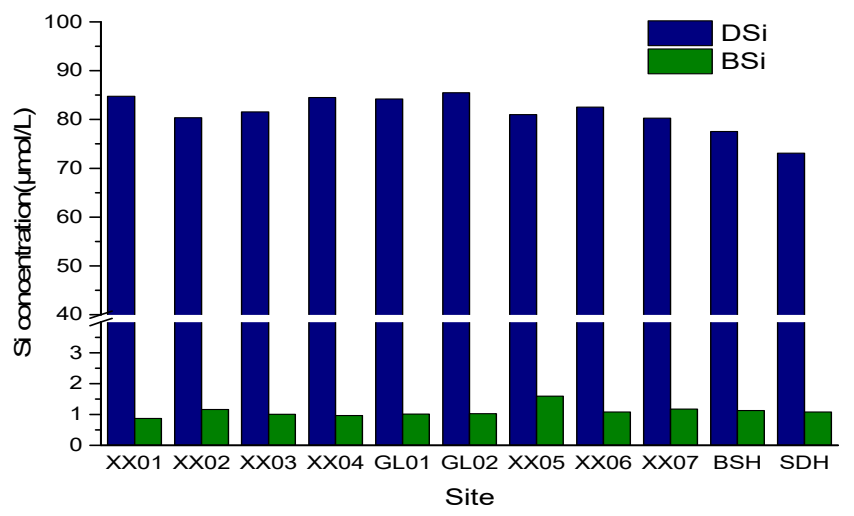

Figure 2. DSi and BSi concentrations at each site (mean value, $\mathrm{N}=23$ at each site).

Spatially, DSi was high in the middle of the Xiangxi River and exhibited a decreasing trend upstream. DSi was lower at BSH and SDH than at other sites. The BSi concentration showed an increasing trend from downstream to upstream (Figure 2).

The peak BSi concentration was observed in the spring and autumn seasons, and its maximum concentration in the riverine zone was higher than that in the lacustrine zone. The BSi concentration ranged from below the detection limit to $4.51 \mu \mathrm{mol} / \mathrm{L}$ in the lacustrine zone, and it reached its peak concentration $(10.89 \mu \mathrm{mol} / \mathrm{L})$ in the riverine zone. Furthermore, the lacustrine zone exhibited a high 
BSi concentration in summer 2016. During the same period, BSi in the riverine zone was lower than in the lacustrine zone $(t=-2.181, P=0.052)$ (Figure 3).

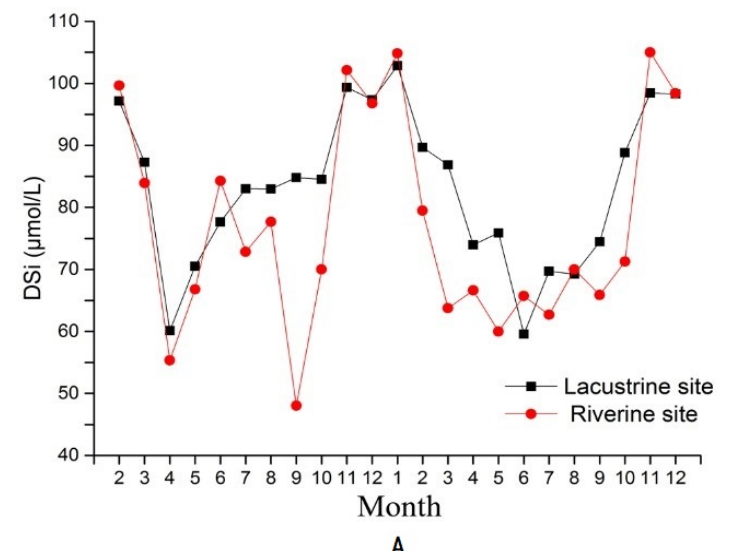

A

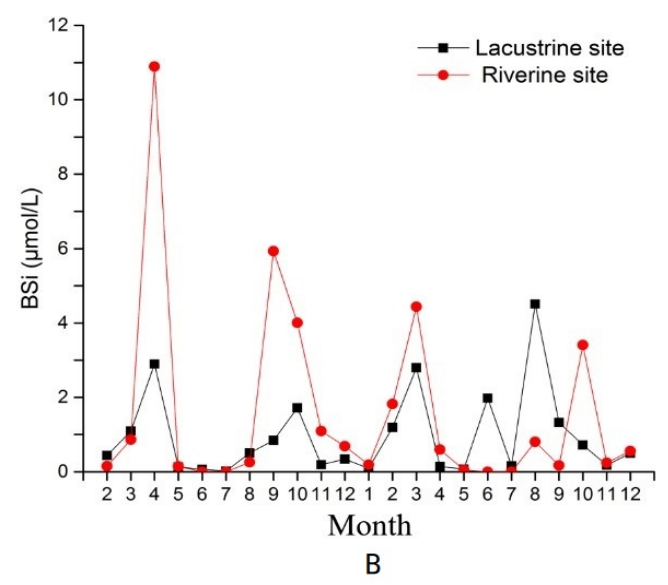

Figure 3. Monthly DSi (A) and BSi (B) variation (mean value, $\mathrm{n}=21$ for lacustrine site, $\mathrm{n}=6$ for riverine site in each month) from February 2015 to December 2016. Spring: March May; Summer: June August; Autumn: September $\sim$ November; Winter: December $\sim$ February.

There were mainly 15 kinds of diatoms detected from the Xiangxi River, Cyclotella, Melosira, Amphiprora and Synedra were the most frequent genus. The diatom cell density showed a decreasing trend from downstream to upstream (Figure 4A). Pennate diatoms exhibited an increasing trend (Figure 4B), among them, the increase of Synedra and Amphiprora was rather obvious. The total cell density of diatoms in the lacustrine zone ranged from $6.20 \times 10^{5}$ cells/L to $9.97 \times 10^{7}$ cells $/ \mathrm{L}$, which was significantly higher than that in the riverine zone $\left(7.90 \times 10^{4} \sim 1.81 \times 10^{7}\right.$ cells/ $\left./ \mathrm{L}\right)(\mathrm{t}=2.13, P=0.05)$. Seasonal trends of BSi showed that in winter, cell density in both zones was low, but it increased dramatically in spring and autumn. However, in addition to spring and winter, summer was also a growth season for diatoms in the lacustrine zone because the peak diatom cell density was observed in summer (Figure 4C). Spearman correlation analysis showed that the diatom cell density had a significant positive relationship with $\mathrm{BSi}, \mathrm{Chl}$ a, and $\operatorname{COD}(P<0.01)$ and a negative relationship with water velocity $(P<0.01)$ in both zones (Table 2$)$. DSi was negatively correlated with the cell density in the lacustrine zone $(P<0.01)$, but no correlation was found in the riverine zone (Table 2$)$.

Table 2. Spearman correlation between cell density and environmental parameters (dissolved silicon (DSi), biogenic silicon (BSi), chlorophyll a (Chl a), $\mathrm{pH}$, water temperature (WT), dissolved oxygen (DO), chemical oxygen demand (COD), conductivity (Cond), and water velocity) in the lacustrine zone $(\mathrm{L}-\mathrm{CD})$ and riverine zone (R-CD).

\begin{tabular}{cccccccccc}
\hline Site & DSi & BSi & Chla & pH & WT & DO & COD & Cond & Water Velocity \\
\hline L-CD & $-0.513^{* *}$ & $0.639^{* *}$ & $0.722^{* *}$ & $0.625^{* *}$ & 0.164 & $0.506^{*}$ & $0.522^{*}$ & -0.024 & $-0.549^{*}$ \\
\hline R-CD & 0.017 & $0.830^{* *}$ & $0.755^{* *}$ & 0.258 & -0.071 & 0.265 & $0.415^{*}$ & $0.497^{*}$ & $-0.745^{* *}$ \\
\hline
\end{tabular}

${ }^{*}$ Correlation was significant at the 0.05 level; ${ }^{* *}$ Correlation was significant at the 0.01 level.

DSi showed a linear decrease as a function of diatom cell density in the lacustrine zone, but it was not obvious in the riverine zone (Figure 5). BSi was linearly correlated with diatom cell density in both zones. The regression model showed that cell density explained $48 \%$ of the BSi concentration variation $\left(R^{2}=0.48\right)$, while the slope in the riverine zone was significantly higher than that in the lacustrine zone $(P<0.001)$. The intercept of the riverine zone was significantly lower than that of the lacustrine zone $(P=0.003)$. From the model, it could be speculated that the BSi concentration in the riverine zone was an order of magnitude lower than that in the lacustrine zone (Figure 6). 

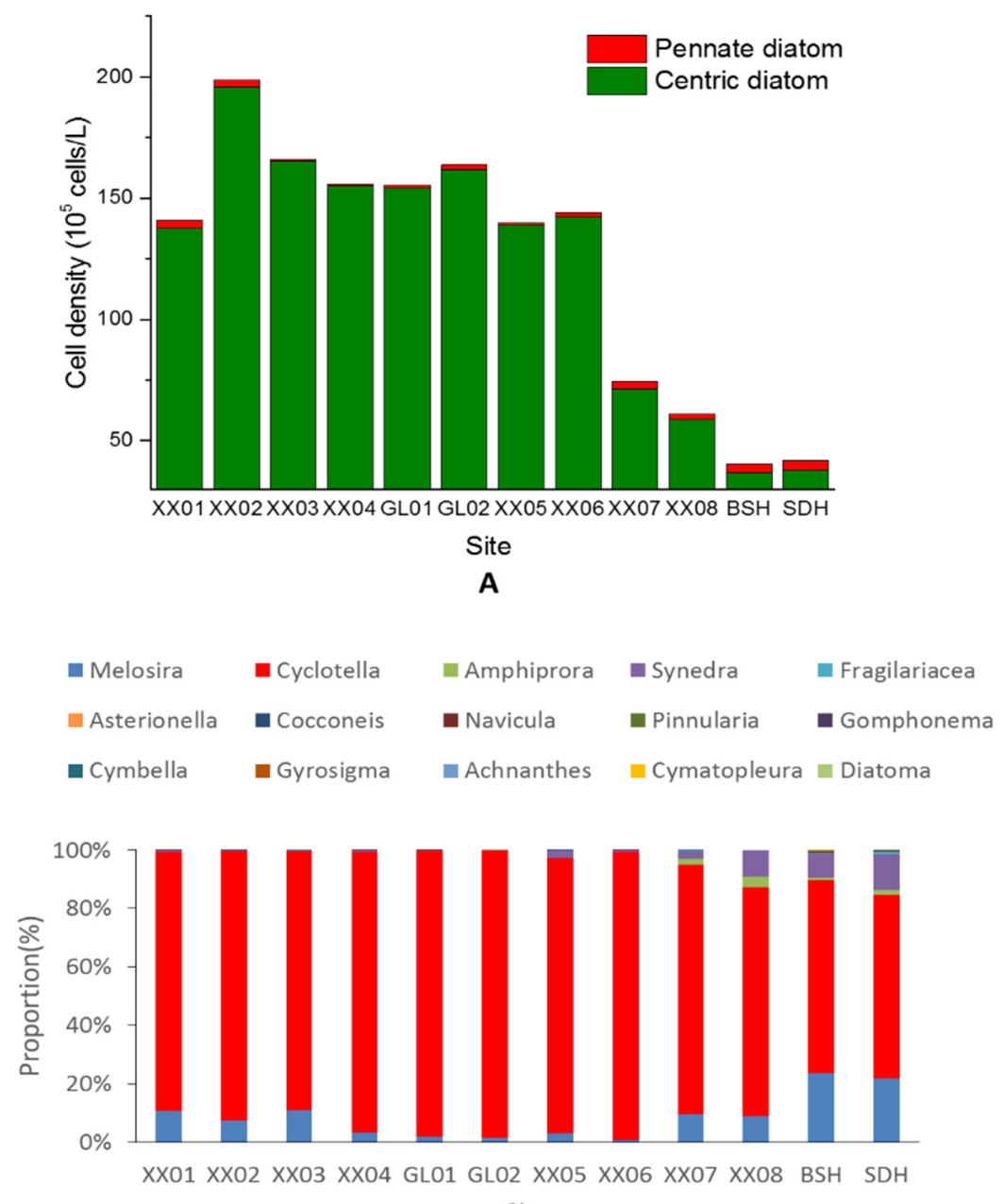

Site

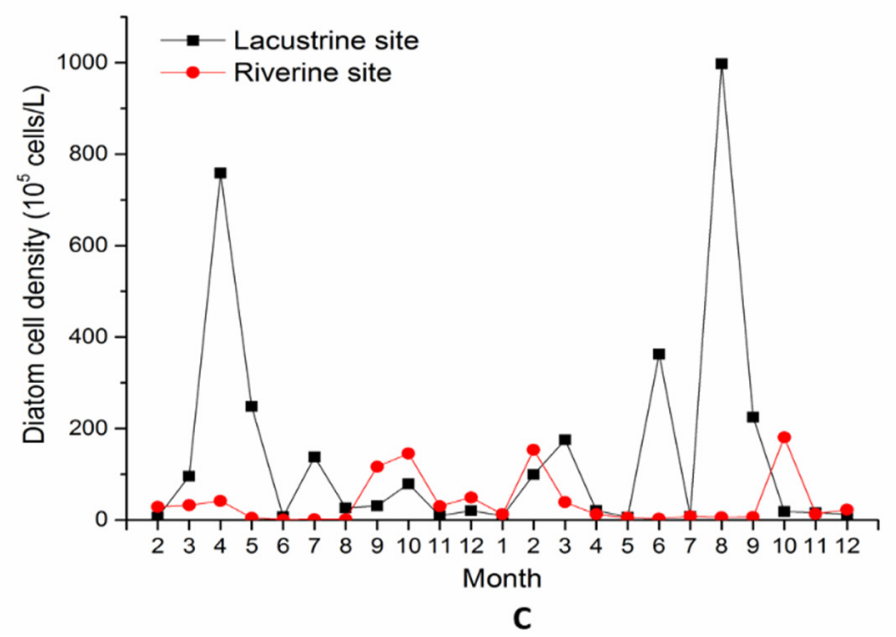

Figure 4. The diatom cell density (A) and proportion of pennate diatom cell density (B) at different sites. Monthly diatom cell density from February 2015 to December 2016 (C). 


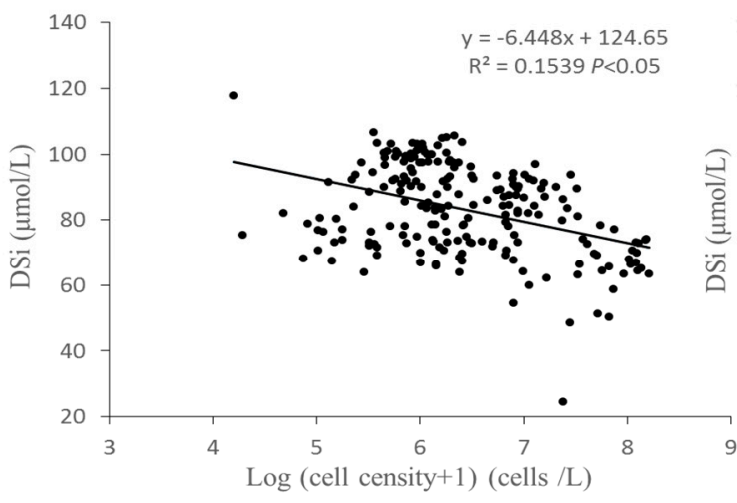

A

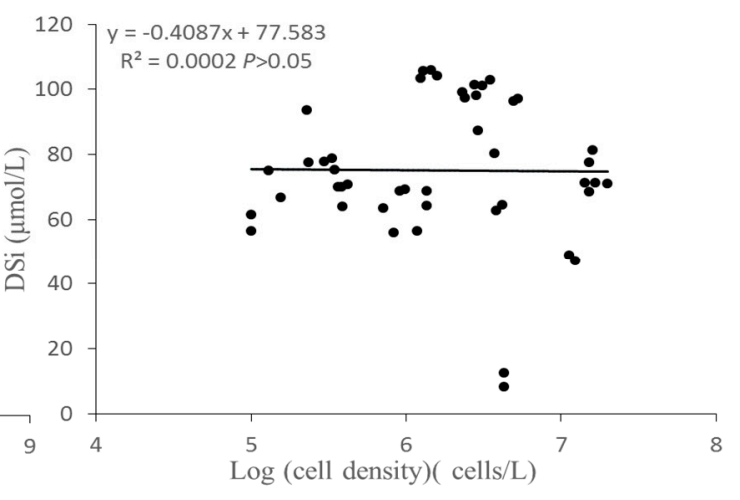

B

Figure 5. Relationships between diatom cell density and DSi in the lacustrine zone (A) and riverine zone (B).

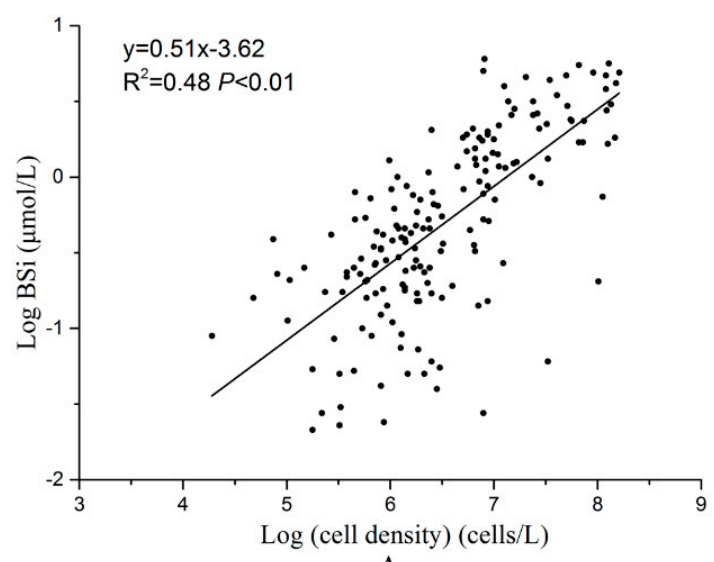

A

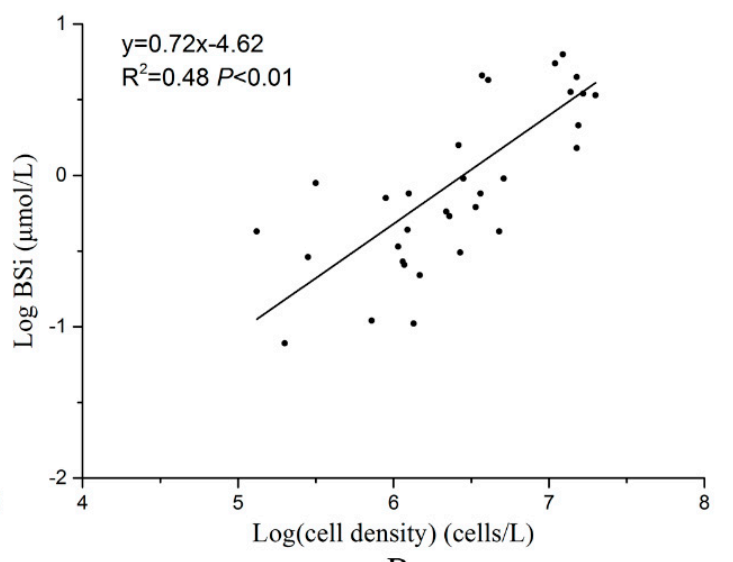

B

Figure 6. Relationships between diatom cell density and BSi in the lacustrine zone (A) and riverine zone (B).

\subsection{Effects of Environmental Variables on Diatom Composition}

Different dominant diatom species were identified from the two zones. In summer, there was a significantly higher proportion of pennate diatoms in the riverine zone than in the lacustrine zone $(\mathrm{t}=8.205, P<0.01)$. In the riverine zone, pennate diatoms occupied over $30 \%$ of the total diatom cell density. However, this proportion never exceeded $10 \%$ in the lacustrine zone. In winter and spring, there was no significant difference in the diatom community structure at both zones, and centric diatoms were the dominant species (Figure 7).

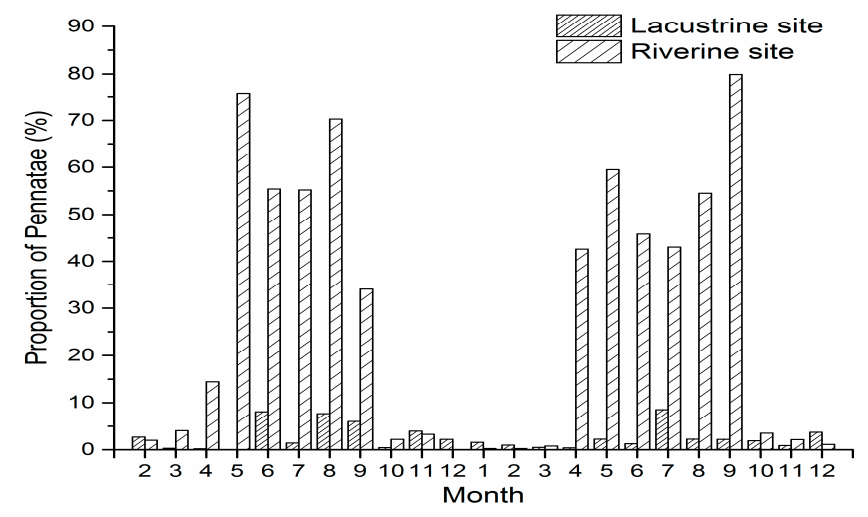

Figure 7. Monthly variation of pennate diatoms in the lacustrine zone and the riverine zone. 
In Figure 8, environmental variables were standardised by normalisation, and diatom species samples were centered. A forward-selected RDA of the diatom species data set revealed water velocity $(\mathrm{F}=52.34, P=0.002), \mathrm{DSi}(\mathrm{F}=20.15, P=0.002), \mathrm{COD}(\mathrm{F}=3.85, P=0.044)$, and $\mathrm{DO}(\mathrm{F}=10.62, P=0.002)$ as the minimum set of significant environmental variables that could describe the greatest variation in the data set; a total $77.3 \%$ of the variation in taxonomic compositions was explained. Pennate diatoms showed a significant positive correlation with water velocity, while centric diatoms were negatively correlated with water velocity $(P<0.05)$. A negative correlation between pennate diatoms and DSi was observed, but this relationship was not evident between centric diatoms and DSi.

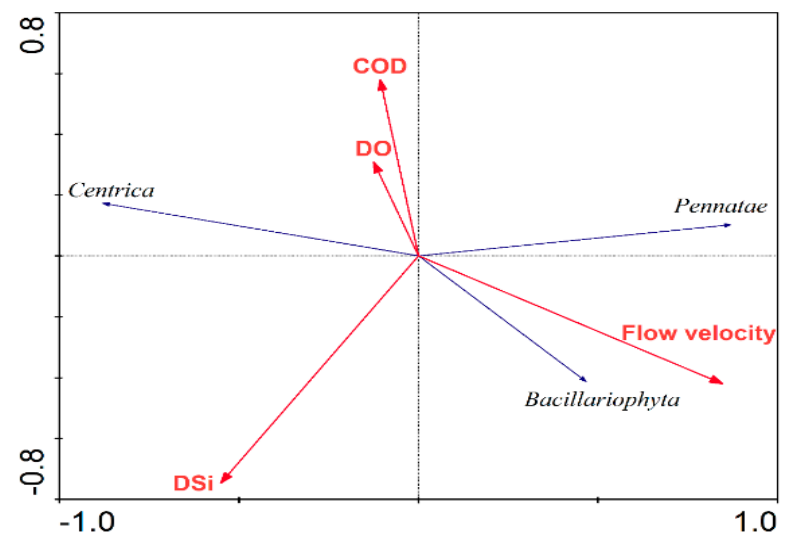

Figure 8. Biplot diagrams for the RDA of the relationship between diatom composition and environmental variables.

\section{Discussion}

\subsection{Variation in the Diatom Community}

The cell density and species composition of diatoms showed significant differences between the lacustrine zone and the riverine zone $(P<0.05)$, which represented the effects of the TGR's operation. Higher cell density in the lacustrine zone than in the riverine zone was first attributed to the relatively stable physical conditions (Table 1). However, the negative coefficient between diatom cell density and water velocity was higher in the riverine zone $(r=-0.745)$ than in the lacustrine zone $(r=-0.549)$ (Table 2), indicating a stronger influence of water flow on the diatom cell density in the riverine zone than in the lacustrine zone. The TGR's operation changed the hydrodynamics markedly, and the lacustrine zone showed relatively stable physical conditions. It is well known that the riverine zone showed an obvious flow rhythm, which means there was high flow discharge and water velocity in the summer and autumn seasons and low flow discharge and water velocity in the winter and spring seasons. The lacustrine zone, which is also known as the backwater area, exhibited a sharp slowdown of water velocity that significantly enhanced sedimentation, light penetration and water transparency. The decrease in the nutrient exchange rate accelerated the process of eutrophication. Such physical and chemical environmental conditions favoured the growth of diatoms. In contrast, the riverine zone maintained a natural river status with a low water level, characterised by a higher water velocity and nutrient exchange rate than the lacustrine zone. Diatom growth showed that it was more likely to be influenced by hydrodynamics [15]. This strong influence was particularly evident in the summer and autumn seasons when precipitation and water discharge increased significantly, disturbing the diatom growth and reducing its density dramatically in the riverine zone. Therefore, the TGR's operation enhanced the diatom cell density and prolonged the diatom growth period in the lacustrine zone of the tributary.

While centric diatoms were the dominant species in the lacustrine zone, a high proportion of pennate diatoms were found in the riverine zone in the summer and autumn seasons (Figure 7). They were mainly dominated by pennate diatoms from the genera of Synedra and Navicula. In the winter 
and spring seasons, the proportion of pennate diatoms in both zones was similarly low. This finding was consistent with previous studies showing that centric diatoms were dominant in a lacustrine zone, while pennate diatom growth was favored in a fluvial zone [40]. RDA analysis showed that pennate diatoms had a significant positive correlation with water velocity, while centric diatoms had a negative relationship with water velocity (Figure 8). The deep and slow flowing lacustrine zone provided beneficial growth conditions for the growth of Melosira and Cyclotella, indicating that water velocity was a key factor for the diatom composition. Both lotic and lentic diatoms had different strategies to adapt to distinct physical environments. For example, the increase of small single-celled centric diatoms could resist sinking due to their morphological properties in a stable environment [41]. Moreover, it has been suggested that fluvial algal species such as pennate diatoms have a higher growth rate than lacustrine species [42]. The time to absorb nutrients was limited for fluvial phytoplankton, as these nutrients were transported downstream by the flow. Consequently, the fluvial phytoplankton had to acquire and absorb nutrients faster and more efficiently. Previous studies found that pennate diatoms had a significant increase in affinity for phosphorus compared with centric diatoms. Lotic diatoms also had higher growth rates and photosynthetic efficiencies with small-scale turbulence than those with standing water conditions [43]. These studies demonstrated that pennate diatoms had physiological and morphological advantages over centric diatoms in a turbulent environment. As a result, stable environmental conditions helped centric diatoms outcompete pennate diatoms under the influence of the TGR's operation. This further verified the significant influence of the TGR's operation on the diatom community.

\subsection{Effects of Diatom on Silicon Cycling in the TGR}

It was reported that the silicon content of diatoms varied among species and sizes [44]. In general, pennate diatoms had a larger size than centric diatoms; consequently, a higher BSi per cell could be found in comparison with that for centric diatoms. In this study, a low cell density with high BSi was found in the riverine zone; cell density had a synchronous trend with BSi in the two zones in winter and spring because centric diatoms were the dominant species due to their high growth rates at low water velocity [45]. From the above, it could be concluded that BSi in the water column showed a significant relationship with diatoms.

There was a significant correlation between diatom cell density and BSi in both zones (Table 2), which indicated that BSi originating from watershed terrestrial phytoliths made little contribution to the BSi pool and that the diatom population was the main contributor to BSi. These results were different from some other regions, such as the Scheldt estuary, where BSi did not follow the dynamics of the living diatoms but rather that of suspended particulate matter [46]. Different regions might show different relationships between diatoms and BSi. Furthermore, diatom cell density was linearly positively related to BSi and had the same explanation coefficients for BSi variation in both zones. The slope in the riverine zone was significantly higher than in the lacustrine zone (Figure 6). It was estimated that BSi increased by $3.24 \mu \mathrm{mol} / \mathrm{L}$ when diatom cell density increased by an order of magnitude in the lacustrine zone; whereas it increased by $5.25 \mu \mathrm{mol} / \mathrm{L}$ when diatom cell density expanded an order of magnitude in the riverine zone. Therefore, diatoms in the riverine zone contained more silicon per cell than those in the lacustrine zone. This phenomenon might be attributed to the distinct diatom composition and provides further evidence that the diatom population was the main contributor to BSi in the tributary of the TGR.

While DSi concentration was sensitive to rapidly changing hydrological conditions [47], some studies have shown diatom blooms were the cause of an intense seasonal decline of DSi concentrations in eutrophic rivers [48]. Our results showed that DSi was negatively correlated with the diatom cell density in the lacustrine zone (Table 2). The regression model indicated that diatom assimilation was the primary reason for DSi decline in the lacustrine zone (Figure 5A). It could be speculated that when the cell density increased by an order of magnitude, the DSi concentration decreased by $6.45 \mu \mathrm{mol} / \mathrm{L}$. However, no correlation was found between DSi and diatom cell density in the riverine 
zone (Figure 5B). This was probably due to hydrodynamic disturbance of the DSi assimilation by diatoms, especially in summer when the water velocity and turbidity were high. This phenomenon was consistent with previous studies showing that DSi was primarily affected by discharge, not diatom uptake, in the fluvial system [15]. The DSi concentration was higher than the threshold of $2 \mu \mathrm{mol} / \mathrm{L}$ for diatom growth [7] in both zones, even in the growth period when DSi was assimilated intensively (Figure 3A). Moreover, when diatom cell density was low in both zones, the DSi concentration was relatively high, with no significant difference in the two zones (Figure 3A). If diatoms in the two zones were taken into consideration together, cell density had little correlation with DSi (Figure 8), indicating that the diatoms were not silicon limited. Thus, silicon cycling was more likely to be affected by diatoms, not vice versa.

There are two possible reasons for silicon cycling alterations by diatoms from the above discussions. On the one hand, diatom succession from pennate to centric would reduce BSi in the water despite high centric diatom cell density. On the other hand, centric diatom bloom promotes silicon cycling efficiency in the reservoir, but exerts a negative influence on the downstream river and its adjacent estuary. Sediment and dissolution processes cause silicon accumulation, becoming a silicon source in the reservoir but in the long term acts as a silicon sink [49]. Therefore, the silicon load transported downstream and to the estuary was reduced. Silicon decreased with the anthropogenic enrichment of nitrogen and phosphorus, which changed the algal community, leading to the dominance of non-siliceous algae. Considering that diatoms contribute approximately $40 \%$ of the global marine primary productivity [50], silicon retention caused by dams may exert great effects on the structure and function of aquatic ecology.

\section{Conclusions}

The diatom cell density in the lacustrine zone was higher than that in the riverine zone. Water velocity was a key factor in determining the diatom species composition; centric diatoms were the dominant species in the lacustrine zone, and pennate diatoms were the primary species in the riverine zone, which indicated that centric diatoms outcompete pennate diatoms under the influence of the TGR's operation. The main contributor to BSi in the tributary of the TGR was diatoms, but DSi was primarily affected by water discharge, not diatom uptake. It could be deduced that silicon cycling was significantly affected by diatoms, but the current concentration of dissolved silicon was sufficient for diatom growth, and there were no significant effects on the diatom community.

Author Contributions: Y.B., H.W. were responsible for the research design. W.X., Y.H. drafted the main text and polished the manuscript. W.M. analyzed the data and prepared the figures. All authors participated in discussions and approved the final manuscript.

Funding: This research was funded by the Science and Technology Research Project of China Three Gorges Corporation (No. 0704098) and the National Natural Science Foundation of China (No. 31123001).

Conflicts of Interest: The authors declare no conflict of interest.

\section{References}

1. Dürr, H.H.; Meybeck, M.; Hartmann, J.; Laruelle, G.G.; Roubeix, V. Global spatial distribution of natural riverine silica inputs to the coastal zone. Biogeosciences 2011, 8, 597-620. [CrossRef]

2. Parker, J.I.; Conway, H.L.; Yaguchi, E.M. Dissolution of Diatom Frustules and Recycling of Amorphous Silicon in Lake Michigan. J. Fish. Res. Board Can. 1977, 34, 545-551. [CrossRef]

3. Tréguer, P.; Pondaven, P. Silica control of carbon dioxide. Nature 2000, 406, 358-359. [CrossRef] [PubMed]

4. Admiraal, W.; Breugem, P.; Jacobs, D.M.L.H.A.; Steveninck, E.D.D.R.V. Fixation of dissolved silicate and sedimentation of biogenic silicate in the lower river Rhine during diatom blooms. Biogeochemistry 1990, 9, 175-185. [CrossRef]

5. Humborg, C.; Conley, D.J.; Rahm, L. Silicon retention in river basins: far-reaching effects on biogeochemistry and aquatic food webs in coastal marine environments. AMBIO J. Hum. Environ. 2000, 29, 45-51. [CrossRef]

6. Pearson, L.K.; Hendy, C.H.; Hamilton, D.P. Dynamics of silicon in lakes of the Taupo Volcanic Zone, New Zealand, and implications for diatom growth. Inland Waters 2016, 6, 185-198. [CrossRef] 
7. Egge, J.K.; Aksnes, D.L. Silicate as regulating nutrient in phytoplankton competition. Mar. Ecol. Prog. Ser 1992, 83, 281-289. [CrossRef]

8. Scholz, B.; Liebezeit, G. Microphytobenthic dynamics in a Wadden Sea intertidal flat - Part I: Seasonal and spatial variation of diatom communities in relation to macronutrient supply. Eur. J. Phycol. 2012, 47, 105-119. [CrossRef]

9. Trigueros, J.M.; Orive, E. Seasonal variations of diatoms and dinoflagellates in a shallow, temperate estuary, with emphasis on neritic assemblages. Hydrobiologia 2001, 444, 119-133. [CrossRef]

10. Gong, Y.; Hu, H. Effect of silicate and inorganic carbon availability on the growth and competition of a diatom and two red tide dinoflagellates. Phycologia 2014, 53, 433-442. [CrossRef]

11. Wang, B.; Qiu, X.L.; Peng, X.; Wang, F. Phytoplankton community structure and succession in karst cascade reservoirs, SW China. Inland Waters 2018, 8, 229-238. [CrossRef]

12. Li, M.; Xu, K.; Watanabe, M.; Chen, Z. Long-term variations in dissolved silicate, nitrogen, and phosphorus flux from the Yangtze River into the East China Sea and impacts on estuarine ecosystem. Estuar. Coast. Shelf Sci. 2007, 71, 3-12. [CrossRef]

13. López, N.L.; Rondón, C.A.R.; Zapata, A.; Jiménez, J.; Villamil, W.; Arenas, G.; Rincón, C.; Sánchez, T. Factors controlling phytoplankton in tropical high-mountain drinking-water reservoirs. Limnetica 2012, 31, 305-321.

14. Gao, M.; Zhu, K.; Bi, Y.; Hu, Z. Spatiotemporal patterns of surface-suspended particulate matter in the Three Gorges Reservoir. Environ. Sci. Pollut. Res. 2016, 23, 3569-3577. [CrossRef]

15. Arndt, S.; Vanderborght, J.P.; Regnier, P. Diatom growth response to physical forcing in a macrotidal estuary: Coupling hydrodynamics, sediment transport, and biogeochemistry. J. Geophys. Res. Oceans 2007, 112. [CrossRef]

16. Shatwell, T.; Köhler, J.; Nicklisch, A. Temperature and photoperiod interactions with silicon-limited growth and competition of two diatoms. J. Protein Chem. 2013, 7, 509-525. [CrossRef]

17. Shi, Z.; Wang, Y.; Wen, A.; Yan, D.; Chen, J. Tempo-spatial variations of sediment-associated nutrients and contaminants in the Ruxi tributary of the Three Gorges Reservoir, China. J. Mt. Sci. 2018, 15, 319-326. [CrossRef]

18. Zeng, H.; Song, L.; Yu, Z.; Chen, H. Distribution of phytoplankton in the Three-Gorge Reservoir during rainy and dry seasons. Sci. Total Environ. 2006, 367, 999-1009. [CrossRef] [PubMed]

19. Li, Z.; Wang, S.; Guo, J.; Fang, F.; Xu, G.; Long, M. Responses of phytoplankton diversity to physical disturbance under manual operation in a large reservoir, China. Hydrobiologia 2012, 684, 45-56. [CrossRef]

20. Peng, C.; Lang, Z.; Zheng, Y.; Li, D. Seasonal succession of phytoplankton in response to the variation of environmental factors in the Gaolan River, Three Gorges Reservoir, China. Chin. J. Oceanol. Limnol. 2013, 31, 737-749. [CrossRef]

21. Ran, X.; Bouwman, L.; Yu, Z.; Beusen, A.; Chen, H.; Yao, Q. Nitrogen transport, transformation, and retention in the Three Gorges Reservoir: A mass balance approach. Limnol. Oceanogr. 2017, 62, 2323-2337. [CrossRef]

22. Ran, X.; Chen, H.; Wei, J.; Yao, Q.; Mi, T.; Yu, Z. Phosphorus speciation, transformation and retention in the Three Gorges Reservoir, China. Mar. Freshw. Res. 2015, 67, 209-228. [CrossRef]

23. Yan, Q.; Yu, Y.; Feng, W.; Yu, Z.; Chen, H. Plankton community composition in the Three Gorges Reservoir Region revealed by PCR-DGGE and its relationships with environmental factors. J. Environ. Sci. 2008, 20, 732-738. [CrossRef]

24. Zhou, G.; Zhao, X.; Bi, Y.; Liang, Y.; Hu, J.; Yang, M.; Mei, Y.; Zhu, K.; Zhang, L.; Hu, Z. Phytoplankton variation and its relationship with the environment in Xiangxi Bay in spring after damming of the Three-Gorges, China. Environ. Monit. Assess. 2011, 176, 125-141. [CrossRef] [PubMed]

25. Mao, J.; Jiang, D.; Dai, H. Spatial-temporal hydrodynamic and algal bloom modelling analysis of a reservoir tributary embayment. J. Hydro-environ. Res. 2015, 9, 200-215. [CrossRef]

26. Zhao, Y.; Zheng, B.; Wang, L.; Qin, Y.; Li, H.; Cao, W. Characterization of Mixing Processes in the Confluence Zone between the Three Gorges Reservoir Mainstream and the Daning River Using Stable Isotope Analysis. Environ. Sci. Technol. 2015, 50, 9907. [CrossRef] [PubMed]

27. Yang, Z.; Cheng, B.; Xu, Y.; Liu, D.; Ma, J.; Ji, D. Stable isotopes in water indicate sources of nutrients that drive algal blooms in the tributary bay of a subtropical reservoir. Sci. Total Environ. 2018, 634, 205-213. [CrossRef]

28. Ran, X.; Liu, S.; Liu, J.; Zang, J.; Che, H.; Ma, Y.; Wang, Y. Composition and variability in the export of biogenic silica in the Changiiang River and the effect of Three Gorges Reservoir. Sci. Total Environ. 2016, 571, 1191-1199. [CrossRef]

29. Ran, X.; Yu, Z.; Chen, H. Silicon and sediment transport of the Changjiang River (Yangtze River): Could the Three Gorges Reservoir be a filter? Environ. Earth Sci. 2013, 70, 1881-1893. 
30. Zhou, C.; Jian-Jun, Y.U.; Li, F.U.; Cui, Y.J.; Liu, D.F.; Jiang, W.; Haffner, D.; Zhang, L. Temporal and Spatial Distribution of Environmental Factors and Phytoplankton During Algal Bloom Season in Pengxi River, Three Gorges Reservoir. Environ. Sci. 2016, 37, 873-883.

31. Han, C.; Zheng, B.; Qin, Y.; Ma, Y.; Yang, C.; Liu, Z.; Cao, W.; Chi, M. Impact of upstream river inputs and reservoir operation on phosphorus fractions in water-particulate phases in the Three Gorges Reservoir. Sci. Total Environ. 2018, 610, 1546-1556. [CrossRef] [PubMed]

32. Ran, X.; Yu, Z.; Yao, Q.; Chen, H.; Guo, H. Silica retention in the Three Gorges reservoir. Biogeochemistry 2013, 112, 209-228. [CrossRef]

33. Walter, W.G. Standard Methods for the Examination of Water and Wastewater; American Public Health Association: Washington, DC, USA, 1995.

34. Hu, H.J.; Wei, Y.X. The Freshwater Algae of China - Systematics, Taxonomy and Ecology; Science Press: Beijing, China, 2006.

35. Edwards, P.M. Origin 7.0: Scientific Graphing and Data Analysis Software. J. Chem. Inf. Comput. Sci. 2002, 42, 1270-1271. [CrossRef]

36. Vogel, M. Review of SPSS/PC + statistical package. Comput. Stat. Data. Anal. 1988, 6, 71-84. [CrossRef]

37. Peng, L.; Tong, T. A note on a two-sample T test with one variance unknown. Stat. Methodol. 2011, 8, 528-534. [CrossRef]

38. Curran, P.A. Monte Carlo error analyses of Spearman's rank test. arXiv 2014, 1411, 3816.

39. Ter Braak, C.J.F. Canonical Correspondence Analysis: A New Eigenvector Technique for Multivariate Direct Gradient Analysis. Ecology 1986, 67, 1167-1179. [CrossRef]

40. Bahnwart, M.; Hübener, T.; Schubert, H. Downstream changes in phytoplankton composition and biomass in a lowland river-lake system (Warnow River, Germany). Hydrobiologia 1998, 391, 99-111. [CrossRef]

41. Moss, B.; Balls, H. Phytoplankton distribution in a floodplain lake and river system. II Seasonal changes in the phytoplankton communities and their control by hydrology and nutrient availability. J. Plankton Res. 1989, 11, 839-867. [CrossRef]

42. Wetzel, R.G. Limnology: lake and river ecosystems. Eos Trans. Am. Geophys. Union 2001, 21, 1-9.

43. Wang, P.; Shen, H.; Xie, P. Can Hydrodynamics Change Phosphorus Strategies of Diatoms?-Nutrient Levels and Diatom Blooms in Lotic and Lentic Ecosystems. Microb. Ecol. 2012, 63, 369-382. [CrossRef] [PubMed]

44. Durbin, E.G. Studies of the autoecology of the marine diatom Thalassiosira nordenskioeldii. II. The influence of cell size on growth rate, and carbon, nitrogen, chlorophyll a and silica content. J. Phycol. 1977, 13, 150-155.

45. Mitrovic, S.M.; Hitchcock, J.N.; Davie, A.W.; Ryan, D.A. Growth responses of Cyclotella meneghiniana (Bacillariophyceae) to various temperatures. J. Plankton Res. 2010, 32, 1217-1221. [CrossRef]

46. Carbonnel, V.; Vanderborght, J.P.; Lionard, M. Diatoms, silicic acid and biogenic silica dynamics along the salinity; gradient of the Scheldt estuary (Belgium/The Netherlands). Biogeochemistry 2013, 113, 657-682. [CrossRef]

47. Chen, N.; Wu, Y.; Wu, J.; Yan, X.; Hong, H. Natural and human influences on dissolved silica export from watershed to coast in Southeast China. J. Geophys. Res. Biogeosci. 2014, 119, 95-109. [CrossRef]

48. Triplett, L.D.; Engstrom, D.R.; Conley, D.J. Changes in amorphous silica sequestration with eutrophication of riverine impoundments. Biogeochemistry 2012, 108, 413-427. [CrossRef]

49. Panizzo, V.N.; Swann, G.E.A.; Mackay, A.W.; Vologina, E.; Alleman, L.; André, L.; Pashley, V.H.; Horstwood, M.S.A. Constraining modern-day silicon cycling in Lake Baikal. Global Biogeochem. Cycles 2017, 31, 556-574. [CrossRef]

50. Nelson, D.M.; Tréguer, P.; Brzezinski, M.A.; Leynaert, A.; Quéguiner, B. Production and dissolution of biogenic silica in the ocean: revised global estimates, comparison with regional data and relationship to biogenic sedimentation. Global Biogeochem. Cycles 1995, 9, 359-372. [CrossRef]

(C) 2019 by the authors. Licensee MDPI, Basel, Switzerland. This article is an open access article distributed under the terms and conditions of the Creative Commons Attribution (CC BY) license (http://creativecommons.org/licenses/by/4.0/). 